ISSN: $1412-4734$

E-ISSN: 2407-8646

Volume 18, Number 1, 2018

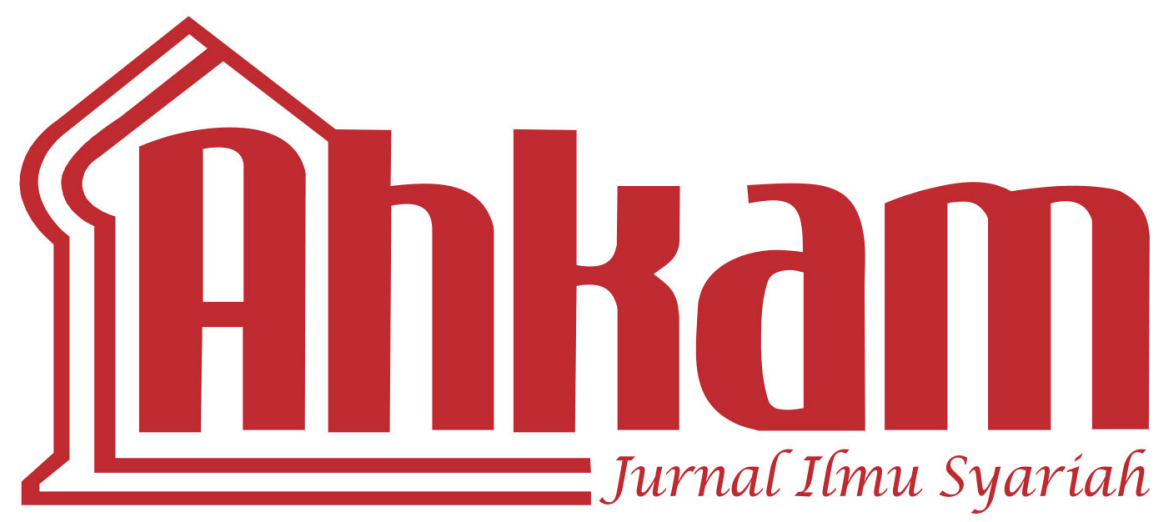

* Herdi Sahrasad \& Al Chaidar

Indonesian Terrorist, ISIS, and Globalization of Terror: A Perspective

* Hotnidah Nasution

Implementation of the Principle of Ultra Petitum Partium in Deciding Children Livelihood in Divorce Lawsuit in Religious Courts

* Havis Aravik, Choiriyah \& Saprida

Critical Study on the Legal Thinking of Muhammad Shahrur

* Nita Triana

Urgency of Arbitration Clause in Determining the Resolution of Sharia Economic Disputes

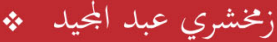

أهمية قوانين المصارف الشرعية في إنلدونيسيا (نظرية التقسير الموضوعى)

* Arrisman

Islamic Law And Business Ethics: Case Study of Forest Fires for Clearing the Lands 


\section{Mhliam}

Volume 18, Number 1, 2018

EDITOR-IN-CHIEF

Khamami Zada

EDITORS

Fathudin

Maman R Hakim

Windy Triana

Nur Hidayah

Ahmad Bahtiar

INTERNATIONAL EDITORIAL BOARD

Tim Lindsey (University of Melbourne Australia)

Nadirsyah Hosen (Monash University Australia)

Ahmad Hidayat Buang (Universiti Malaya Malaysia)

Raihanah Azahari (University Malay Malaysia)

Mark Elwen Cammack (Southwestern University)

Razeen Sappideen (University of Western Sydney)

Carolyn Sappideen (University of Western Sydney)

Nik Ahmad Kamal bin Nik Mahmod (International Islamic Universiti Malaysia)

Ahmad Tholabi Kharlie (UIN Syarif Hidayatullah Jakarta)

Muhammad Atho Mudzhar (UIN Syarif Hidayatullah Jakarta)

Masykuri Abdillah (UIN Syarif Hidayatullah Jakarta)

Muhammad Amin Suma (UIN Syarif Hidayatullah Jakarta)

M. Arsykal Salim GP (UIN Syarif Hidayatullah Jakarta)

Asep Saepudin Jahar (UIN Syarif Hidayatullah Jakarta)

ASSISTANT TO THE EDITORS

Kamal F. Musa

Erwin Hikmatiar

ENGLISH LANGUAGE ADVISOR

Bradley Holland

Umi Kulsum

ARABIC LANGUAGE ADVISOR

Amany Burhanudin Lubis

AHKAM has been accredited based on the determination of Director General of Research Reinforcement and Development, Research, and Technology Ministry of Higher Education of Republic of Indonesia, No. 36/a/E/KPT/2016 (valid until 2021). 
AHKAM Jurnal Ilmu Syariah (ISSN: 1412-4734) is a periodical scientific journal published by Faculty of Sharia and Law of Syarif Hidayatullah State Islamic University Jakarta in collaboration with Indonesian Scientist and Sharia Scholar Association (HISSI). This journal specifically examines the science of sharia and obtains to present various results of current and eminence scientific research. The administrators receive articles as contributions Sharia and Islamic law disciplines from scientists, scholars, professionals, and researchers to be published and disseminated.

\section{EDITORIAL OFFICE:}

Fakultas Syariah dan Hukum UIN Syarif Hidayatullah Jakarta

Jl. Ir. H. Juanda 95 Ciputat, Jakarta 15412

Telp. (+62-21) 74711537, Faks. (+62-21) 7491821

Website: http://journal.uinjkt.ac.id/index.php/ahkam/index

E-mail: Jurnal.ahkam@uinjkt.ac.id 


\section{Table of Contents}

1 Herdi Sahrasad \& Al Chaidar

Indonesian Terrorist, ISIS, and Globalization of Terror:

A Perspective

23 Hotnidah Nasution

Implementation of the Principle of Ultra Petitum Partium in Deciding Children Livelihood in Divorce Lawsuit in Religious Courts

43 Havis Aravik, Choiriyah \& Saprida

Critical Study on The Legal Thinking of Muhammad Shahrur

65 Nita Triana

Urgency of Arbitration Clause in Determining The Resolution of Sharia Economic Disputes

89

زخشري عبد المجيد

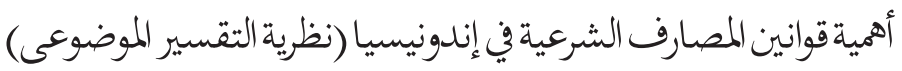


109 Arrisman

Islamic Law and Business Ethics: Case Study of Forest Fires for Clearing The Lands

125 Abdulmajeed Hassan-Bello

Riba and Islamic Banking, Examining the Practices of Jaiz Bank PLC, Nigeria

155 ISNaWATI Rais

Marriage Dispensation due to Extramarital Pregnancy: The Study on the Decision by the Religious Court of South Jakarta (2010-2011)

177 HaMZAH

Zakah Empowerment Optimization Through Baitul Ikhtiar Cooperation as an Effort in Poverty Alleviation in Bogor Regency

201 Abdul Muta'Ali

Israel and Palestine Conflict from Linguistics and Figh

Siyasah Perspective

219 Susiknan Azhari

Tracing the Concept of Fajr in the Islam Mosaic and Modern Science

233 Ahmad Sholihin Siregar

The Construction of Āyātul Aḥkām (Constructing the Selection Bases of Āyātul Aḅkàm) 


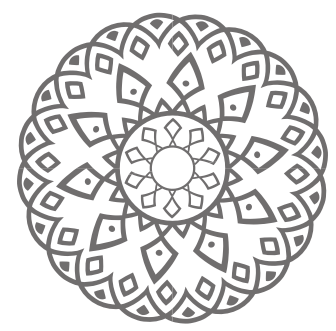

\title{
INDONESIAN TERRORIST, ISIS, AND Globalization of Terror: A Perspective
}

\author{
Herdi Sahrasad \& Al Chaidar
}

\begin{abstract}
Abstrak: Terorisme telah menjadi salah satu isu penting di Indonesia. Terakhir, Santoso, seorang teroris terdepan yang berbasis di Poso, Sulawesi Tengah, gerakannya dihentikan. Namun, petualangannya yang radikal di Poso dan Indonesia Timur telah menginspirasi banyak pemuda untuk mengikuti jalan berdarahnya untuk melakukan perang suci melawan demokrasi sekuler di Indonesia. Dalam mengejar Santoso, pertempuran antara pasukan keamanan dan teroris sering terjadi di lapangan. Kelompok Santoso adalah bagian dari jaringan radikal Islam di Asia Tenggara, dan 'solidaritas imajiner' mereka dengan para Islamis radikal Timur Tengah relatif kuat. Dengan demikian, militer membantu polisi untuk memerangi terorisme di Indonesia.
\end{abstract}

Kata kunci: Santoso, ISIS, mujahiddin, terroris, Islamis 
Abstract: Terrorism has been one of the critical issues in Indonesia. Latest, Santoso, a front man of terrorists based in Poso, Central Sulawesi, was terminated. However, his radical adventures in Poso and East Indonesia has inspired many youths to follow his bloody road to carry out a holy war against the secular democracy in Indonesia. The Reform era has led a relatively sharp phase of friction and clash of ideology. A religious ideology, often accompanied by violence and other form of emotional expressions, has transformed into a strong radical opposition ideology, even with a relatively small number of supporters. In many case, they are sporadic, brutal and frightening. The ideology of Islam in Indonesia at this period appears in its hardest and roughest form: terrorism. Santoso group is part of the radical Islamist networks in Southeast Asia, and their 'imagined solidarity' with the Middle East radical Islamists is relatively strong.

Keywords: Santoso, ISIS, mujahiddin, terrorist, Islamist

$$
\begin{aligned}
& \text { ملخص: لقد كان الإرهاب أحد القضايا الحاسمة في إندونيسيا. آخرها، سانتوسو، وهو }
\end{aligned}
$$

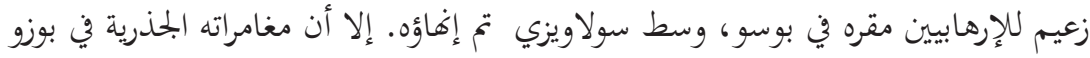

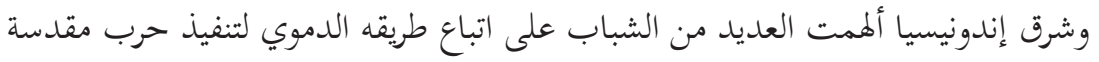

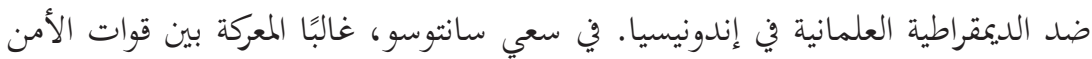

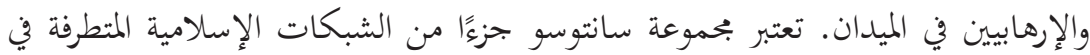

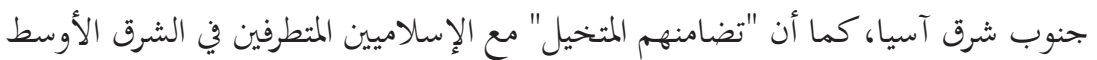

$$
\begin{aligned}
& \text { قويون نسبياً. وهكذا، يساعد الجيش الشرطة على مكافحة الإرهاب في إندان لندونيسيا. } \\
& \text { الكلمات المفتاحية: سانتوسو، ISIS، المحاهديون، إرهابي، إسلامي }
\end{aligned}
$$




\section{Introduction}

After the fall of Soeharto's New Order, Indonesian transformation into a democratic country was followed by various security problems, especially terrorist attacks that shocked the public suddenly. Terrorists' actions and bomb blasts in several cities, together with other forms of social unrest and violent demonstrations occurred throughout the archipelago. As it is known, the history of homegrown radical Islamic groups dates back to the late 1940s, when Kartosuwiryo led the Islamic State of Indonesia (NII) movement, a radical group that led to the formation of the al-Qaeda affiliated Jamaah Islamiyah (JI) in 1993, a group responsible for the deadly 2002 Bali bombings. In October 2002, the US has made JI as an organization of international terrorists. It happened after the UN Security Council added JI as a terrorist group, so that all countries that are members UN organizations are required to freeze the assets of, and deny access to funds of JI.

In UN Resolution 1390/2002 JI has been blamed as a terrorist organization international along with 25 other terrorist organizations. JI is considered as an arm of Al-Qaeda in Southeast Asia. JI is based in Indonesia is believed to have links with other terrorist organizations active in Malaysia, Singapore and the Philippines (Vaughn, 2005:23).

JI as a terrorist network is the largest in Southeast Asia. And it has a network of southern Thailand region to the Australian territory. The terrorist group is increasingly considered to be a serious threat to security regionally in the Southeast Asian region and even internationally, because the brain of perpetrators of acts of terrorism in Southeast Asia is a member of JI. One of JI member, Mas Selamat Kasturi who masterminded the plan to crash the plane into Changi Airport, could be handled. He was arrested in Malaysia and handed over to Singapore. This news is accessible via tail action that occurred in Indonesia culprit is the JI group. The various action has been carried out by JI members as the brains of various acts of terror in Indonesia between the years 2000-2005 such as the Christmas bombings in 2000, 81 bombs and 29 explosions in Jakarta in 2001, the first Bali bombing in 2002, Bom Marriot 2003, Australian Embassy bombing in 2004 and the Bali II 2005 (ICG, 2003: 5). 
Various acts of terrorism that occurred until year 2009 in Indonesia were also not out of the share of the participation of members of JI as the brains behind the terror attacks. Jemaah Islamiyah (JI) is a form of development of the Darul Islam (DI) which is a growing movement of radical Islam in Indonesia in the year 1940s, a movement that wants the exercise to the Islamic Sharia menggantu Dutch government. DI movement is located in West Java, Aceh and Sulawesi. And the third movement DI rebellion has been defeated by the Army National Indonesia (ICG, 2003: 14).

Saeful Mujani, a political scientist of State Islamic University of Jakarta, argued that there is an interconnectivity between external influence from Middle East who has brought Pan-Islamism, Muslim Brotherhood, and global caliphate and Muslims in Indonesia2. Those ideas are established in contemporary Islamic organization like Jamaah Islamiyah, Jamaah Ansarut Tauhid, Majelis Mujahidin Indonesia, and many others (Gunaratna, 2002; Mujani, 2007; Djelantik, 2006).

Islamic transnational movement has great influence to idea for organizing Islamic movement in Indonesia. Furthermore, Ahmad Syafii Maarif, a well-known scholar and ulama of Muhammadiyah organization in Indonesia, even mentioned that Wahhabism plays a significant role and in fact becomes a role model in creating and converting Muslims in Indonesia into terrorists (Wahid, 2011: 74). Since JI's charismatic leader Abu Bakar Ba'asyir was arrested in August 2010, experts believe that younger JI members separated from the group when senior members decided to lie low, as they believed that Indonesia was no longer a land for jihad. But the facts say otherwise.

In the perspective of social movement theory, the phenomenon of terrorism can not be regarded merely ideological issues, but also issues of sociological imbalances. Such imbalance manifests in the form of social deprivation, economic inequality and political repression. Ideology is only a mass-mobilizing factor to win the sympathy and minds of the people experiencing this sociological imbalance. Therefore, the ideology of terrorism is actually nothing more than a domino effect from the rise of the sociological imbalances. 
In almost the same formulation, Olivier Roy (2004:16) uses the term "social dislocation" as a factor causing the emergence of ideological radicalism and terrorism. He said that the sociological distance between radical groups and other communities contributed to the creation of cognitive disparity and a multitude of misunderstandings between the two that led to violent conflicts. This means that the phenomena of radicalism and terrorism are not always about ideology but can also be rooted in social, political and economic issues (Hilmy, 2016).

In the context of terrorism in Indonesia, precisely the socioeconomic deprivation and political marginalization has encouraged the Islamists to act radically and extremely as they do not see the path of peace as a solution to the problem. Sociological imbalances in turn creates what is called the M Hafez Mohammed and Quintan Wiktorowicz (2004: 65) is an "opportunity structure" for the appearance of an actors or institutions to establish an ideological opposition and resistance to mobilize the masses (Hilmy, 2016). Both refer to the presence of the alliance, state repression, political instability and the strength or weakness of state institutions. Analysis of the structure of opportunity finally talk about the broader context of how the actors can use the opportunities and threats to mobilize the masses.

In the context of Indonesian terrorism, the rise of jihadists is inseparable from the presence of these opportunity structures. Just to name a few, Imam Samudera, Azhari, Noordin Mohd Top, Santoso, and Maman Abdurrahman are terrorists whose names became known through the presence of opportunity structures. They used their intelligence to frame a narration of terrorist resistance to persuade grassroots victims of sociological imbalance (Hilmy, 2016). The death of all of terrorist frontmen such as Santoso, Azhari, Noordin Mohd Top, Imam Samudera etc proved even inspire other individuals, especially the radical Muslims, to lead a terrorist group. Therefore, it obviously will not be able to break the ideological reproduction of terrorism from the original source.

Many operations to eliminate terrorists may be held, but the chain of ideological terrorism will never break up if the government ignores the sociological imbalances above. As a result, the emergence of new terrorist and other figures just a matter of time. 
To a certain extent the collective memory of people still remember the occurrence of various bomb attacks by terrorists. Even, the Indonesian public was especially shocked by 13 bombs that exploded almost simultaneously in several cities in Indonesia on Christmas Eve, 25 December 2000. These attacks were part of a high-scale terrorist attack by Al Qaeda and Jemaah Islamiyah (JI) .The attack involved a series of coordinated bombings of churches in Jakarta and eight other cities which killed 18 people and injured many others.

In the following year (2001), 81 bombs exploded, 29 explosions happened in Jakarta. The most significant one in terms of number of victims and international coverage was the first Bali bomb blast on 12 Oct 2002. Ali Imron is the designer and maker of bombs in cafes of Paddy`s Pub and the Sari Club in Kuta, Legian, Bali on October 22, 2002. The first Bali bombing has been into mourning for the whole world because about 202 people, including 164 foreign tourists were killed pathetically in the incident. Ali Imron from behind prison reminded us, only 10 of the 400 alumni of Afghanistan who commit acts of terrorism involving Santoso in their action and it's been shocking the world. What if hundreds of others doing the same abominations? It was horrible (Interview with Ali Imron in Jakarta, July 20-30, 2016).

The tragedy was repeated in the following year when a suicide bomber exploded the lobby of the J.W Marriott hotel in Jakarta in August 2003, in front of the Australian Embassy in 2004, and the second Bali bomb on 1 October 2005 (Djelantik, 2006).

After three years of relative quiet of bomb attacks, suddenly in Jakarta on July 17, 2009, two powerful explosions occurred at the JW Marriott and Ritz-Carlton, Jakarta. The explosion occurred almost simultaneously at around 7:50 pm. The Suicide bombings killed at least nine people and injured more than 50 others, either Indonesian or foreign nationals.

Later in January 2010, there was a terrorist shooting of civilians in Aceh and CIMB Niaga Bank robbery in September 2010.Then, there is blasting of bomb in Cirebon, April 15, 2011. The explosion of a suicide bombing was also occurred in the Police Mosque Cirebon when 
the Friday Praying was went on, that killed the perpetrator and injured 25 others. Then, terrorist bombing in Gading Serpong happened, in April 22, 2011. The terrorists made a plan to target the Christ Church Cathedral in Serpong, South Tangerang, Banten and they placed the bomb in a gas pipeline, but the police can handled and put down this terrorist action (Antara, 21 Juli 2009).

Then, there was a bomb explosion in Solo, September 25, 2011. The explosion of a suicide bombing in the churh of GBIS Kepunton, Solo, Central Java happened after the church service and the congregation out of the church. One suicide bombers were killed and 28 others injured.

There was another bomb blast in Solo, August 19, 2012. The grenade exploded in Pospam Gladak, Solo, Central Java. Then, in Poso, terrorists attack the Police with bombing in June 9, 2013 with the target of police personnel who were apples morning. The bomb exploded in front of the mosque Mapolres Poso, Central Sulawesi. one officer wounded seriously, while a suicide bomber killed on the spot. And in January 2016, terrorist bombings and crossfire occurred in Jakarta. The explosion and firefight around Plaza Sarinah, Jalan MH Thamrin, Central Jakarta, in which 8 persons killed, two of them are perpetrators of the attack (Metrotvnews, 17 Januari 2016).

On July 5, 2016, suicide bomb exploded in the courtyard of Investigation Police Headquarters Kota Surakarta, Central Java, one offender was killed and one police officer were injured. All of the above terrorist actions were proof and a sign that terrorism is still rampant in the country under reform era of President Susilo Bambang Yudhoyono and Joko Widodo.

In addition to facing the problem of terrorism, the post-Suharto era has also been marked by the proliferation of Islamic movements that run the gamut from violent to peaceful, from 'democratic' to antidemocratic. Among new Islamic movements that use violence to achieve their goals are the Front Pembela Islam (the Islamic Defenders' Front or FPI), and Laskar Jihad (the Jihad Troops), to mention a few notorious groups. Although Majelis Mujahidin Indonesia (MMI, the Indonesian Mujahidin Council) and Mujahiddin Indonesia Timur (Mujahiddin of East Indonesia-MIT) described itself as a non-violent organisation, the 
group does not repudiate the use of force. Hizbut Tahrir (the Party of Liberation) is a non-violent organisation, but it strongly opposes the notion of democracy and that of the nation-state (Zada, 2002; Jamhari and Jahroni, 2004; Hasan, 2002).

\section{Bali Bomb: Emergence of Terror}

In fact, the emergence of the issue of terrorism as a serious problem occurred after the first Bali bomb blast in 2002, an event that shocked the community and the country amid weakening the power of the government address social problems in Indonesia. In the early 2000s, a range of jihadist groups operated across the Indonesian archipelago. These were not initially considered a major security concern by the government, as Indonesia prioritized rebuilding its economy after the Asian Financial Crisis and consolidating its democracy after overcoming a 32-year-long dictatorship. Additionally, most of these groups confined their violence to the islands of Maluku and Sulawesi, where communal conflicts had broken out between Muslims and Christians (Zammit and Iqbal, 2015: 4).

Bali bomb blasts marked the emergence of large-scale terrorism in Indonesia. According to Andrew Zammit and Muhammad Iqbal, following the 2002 Bali bombings, Indonesia confronted a seemingly unmanageable terrorist problem. Over the next decade, however, the country became widely viewed as a counter-terrorism success story as the threat from al-Qaeda-linked or -inspired jihadist groups declined dramatically. Unfortunately, the transnational pull of the conflicts in Syria and Iraq, and the emergence of the Islamic State (ISIS), risk undermining Indonesia's counter-terrorism successes (Zammit and Iqbal, 2015: 6).

In this regard, Institute for Policy Analysis of Conflict (IPAC) director Sidney Jones also said that various radical media outlets disseminated IS propaganda by re-making videos or audio statements in Indonesian and spreading the links through the internet every day, making effective use of Indonesia as the fourth leading Facebook user in the world with over 84 percent of users active Twitter users by 2014 (Sapiie, 2015). In this regard, Jemaah Islamiyah (JI) is a radical Muslim group that aspires to establish the Islamic State, and they 
establish transnational networks that have a common interest in the global arena.

In reality, Jemaah Islamiyah (JI), had a close relationship with alQaeda, dating back to the 1980s foreign fighter mobilization against the Soviets in Afghanistan. JI's co-founders Abdullah Sungkar and Abu Bakar Bashir were hesitant to follow Osama bin Laden's 1998 call for attacks on Western military and civilian targets, but one faction of JI chose to join al-Qaeda's global war (Zammit and Iqbal, 2015: 6).

This faction was led by Riduan Isamuddin alias. Hambali, who had a close operational relationship with 9/11 architect Khalid Sheikh Mohammed. Hambali's JI faction bombed churches across Indonesia, unsuccessfully attempted to attack the U.S. Embassy in Singapore and in October 2002, bombed tourist venues in Bali, killing 202 people.

In this connection, Noordin Mohammad Top, one of the Bali bombers, stepped in to Hambali's role and continued attacking Westernassociated targets in Indonesia. His faction bombed the Jakarta Marriot Hotel in September 2003, the Australian Embassy in September 2004 and Bali tourist venues again in October 2005 (Kompas, August 9, 2003.). In this regard, each bombing led to further arrests by Detachment 88, a new counter-terrorism unit within the Indonesian National Police. In response to the crackdown, JI's leadership distanced itself from Noordin's breakaway faction and eschewed mass-casualty attacks on foreign targets. Instead, they sought a secure base in Poso, a Sulawesi town recovering from recent communal conflict. JI's Poso network focused on killing Christians and government officials, and in 2005, the JI shocked the nation by beheading three Christian schoolgirls (Jakarta Post, April 26, 2013).

The battle between security forces and terrorists often happens in the field. The Network of JI terrorists in Southeast Asia and the Middle East are relatively strong. So that the military help the police to combat terrorism in Indonesia. In 2007, Detachment 88 killed and arrested many members of the network, prompting JI to cease violence and focus on gradually rebuilding itself.

By fast motion operation of police and military in tackling JI terrorism, JI gradually can be trimmed and attenuated. JI was further 
weakened in 2008, when their former leader Abu Bakar Bashir created a new organization, Jemaah Ansharut Tauhid (JAT), taking many JI members with him. Noordin's network, also weakened by counterterrorism efforts, failed to launch another major attack until July 2009, when it bombed Jakarta's Marriot and Ritz-Carlton hotels. Detachment 88 killed Noordin in raids after the attack, and his network did not recover (The Jakarta Post, August 8, 2009). Although the police operation to combat terrorism without ceasing, but the cells and terrorist networks continue to grow. One of the terrorist leaders were wanted by the police is Santoso.

\section{Potrait of Santoso as a Terrorist}

After being chased, attacked and surrounded by about 3,000 police and military forces in the forest area of Poso, Central Sulawesi, finally Santoso (Abu Wardah), as a fugitive terrorist be terminated. In our opinion, this is "the struggle for the real" (to borrow a Clifford Geertz's metaphor) by the Police/Army of Indonesia to address challenges Santoso group who feel mightyand powerful in the Poso jungle.

Observers of terrorism estimate that Santoso group has networking with radical groups that spread in Indonesia and the Philippines, and have sympathizers in various parts of Southeast Asia. In a report from the International Crisis Group in 2012, titled "How Indonesian Extremists Regroup”, it was disclosed that JI affiliates in Poso were based in Tanah Runtuh, while elements of KOMPAK were based in Kayamanya. After the Malino peace declaration in 2001, Santoso was also active in the Tanah Runtuh group (Kompas, Juli 20, 2016).

In terms of his criminal record, Santoso's name was later detected when he was involved in the robbery of a truck transporting cigarette products from a well-known company in August 2004. The action was deemed fäi (robbery to finance terror acts), which was considered a form of war.

However, according to information from a member of the Tanah Runtuh group, Mua'rifin, the dossier of terror convict Abullah Sunata in 2011, the fa'i was an initiative from Santoso himself, not a command 
from the askari military unit of the Poso branch of JI at that time (Kompas, Juli 20, 2016). Not many know that even well behaved, Santoso indeed a radical Islamist, and the action may reflect the early skills of Santoso in carrying out terror acts. This talent was also later responded to by figures in other terror groups, which later led him to occupy more prestigious positions in the terrorist network in Indonesia. This development later led to Santoso beingconsidered quite dangerous by the authorities and he became a major fugitive.

After the events of a major police crackdown in Tanah Runtuh on January 22, 2007, the activities of the violent network in Poso were paralyzed. However, the situation took place over a short time. After the establishment of Jamaah Ansharut Tauhid (JAT) in Java in 2008, the remnants of terror groups in Poso reconsolidated (Kompas, Juli 20, 2016). Around the same time, after serving a three-year sentence, Santoso in 2009 started his struggle to make Poso a land of jihad.

Around the end of 2009, two former JI members went to Poso to talk with Santoso about the possibility of opening JAT branches there. At the same time, the idea of opening a military training camp in Jantho, Aceh, was also being considered by JAT, although it was later stopped by the authorities in February 2010. During 2009, Santoso formed a small group that intensively discussed various Islamic teachings. Then, in 2010, the group started to conduct military training in Tamanjeka hamlet, Poso (Kompas, Juli 20, 2016). The group, which consisted of only about 10 people, increasingly conducted military training after Daeng Koro, alias Sabar Subagyo, joined in 2012. At that time, Daeng Koro had fled from Mindanao, the Philippines.

In January 2011, the JAT branch in Poso was established with Yasin as its amir (leader) and Santoso was appointed as the commander of the military wing. From then, Santoso's degree and rank also rose and were increasingly taken into account (Kompas, Juli 20, 2016). The side effects of the crackdown on the camp in Aceh were an effort to make Poso a military training ground. Santoso held military trainings three times, in January, March and May 2011. He also sought weapons and ammunition through networks in Java. 
Mujahidin of East Indonesia (MIT) led Santoso (Abu Wardah), he believes has been affiliated with ISIS. Remember that an Indonesian citizen named Abu Muhammad al Indonesi are also the Santoso's network, has appeared in a video to invite hundreds other citizens to join ISIS and has recently happened repeatedly departure to Syrian citizen allegedly linked to ISIS.

Again, back to Santoso as the subject matter, in which he has been terminated with all of his radical adventures, then the society and state must remain vigilant and anticipatory. In 2010, Santoso actually followed a deradicalization program provided by the government. One of the projects undertaken by Santoso in the deradicalization program was the cleaning of water pipes in Palu.

Santoso employed a number of his followers in the deradicalization project. However, instead of changing his way of thinking or deradicalizing him, the project became a way for Santoso to consolidate with his colleagues to launch new violent acts (Kompas, Juli 20, 2016). Santoso is one of the terrorists kingpin that had been targeted in the de-radicalization program, but it is proved that he is even more rampant and with a global network of owned, it appears that he was increasingly confident until his death.

Santoso group along with his tissues and cells are already affiliated with ISIS, and that means terrorism in Indonesia has integrated itself with the world-class, global terrorism. Therefore, surveillance in the area where there is a terrorist, should be tightened to restrict their movements. The image of Santoso as ex the government guided deradicalization which proved even became an important figure in the national and global terror networks, should be a important lesson for the country.

Deradicalisation should not just be a "project", because the impact can be fatal and become a boomerang for the government and society. Vigilance, introspective and alertness of the state (and society) will be needed to scrape and tackle terrorism after the killing of Santoso. Counterattack from the Group of Santoso should be anticipated, and very likely "the new Santoso, the other Santoso" would be popping back here and there. That is the challenge for our society and state in the road ahead, related to transnationalization of terrorism and 
globalization of terror complicating the matters in the politicaleconomic sector, security and law under reform era.

\section{Santoso and ISIS}

Santoso group has joined ISIS (Islamic State of Syria and Iraq) and build a power base in Poso to struggle against what the so-called "thaghut regime" (evil regime) in their perception and opinion. ISIS born as a result of the failure of Iraqi leaders, including Prime Minister Nouri al-Maliki in building an inclusive political systemin Iraq. It has given ways to grow militants across Iraq, including the Sunnis, in turn, gave birth to ISIS. Sunni militants protested the economic and political marginalization by the ruling Shi'ite. Supports given by the United States, Saudi Arabia, and Qatar to the hardline oppositions in Syria also contributed to the birth of ISIS. Of course, the presence of ISIS which originated from the Sunni has shocked the Muslim World, including Indonesia. Some call it as the Islamic State in Iraq and the Levant (ISIL) (Clinton, 2014: 6; Kuncahyono, 2014: 8).

There is also a call Islamic State in Iraq and Syria (ISIS), which specifically has a different coveragearea. The term includes the Sham or the Levant region between the Mediterranean Sea and the Euphrates River means that the country coverage includes Jordan, Lebanon, Palestine, and Israel. The term Syria is confined to the state of modern Syria that is currently in conflict.

The genealogy of this radical religious organization can be traced to the Salafi Jihadist movement who have been fighting in Iraq and Syria that are on a mission to the formation of Daulah Islamiyah (Islamic State). ISIS (Islamic State of Iraq and Syria), according to Zana Khasraw Gulmohamad of the University of Sheffield, stems from the birth of Al Qaeda in Iraq (AQI) in 2003 The initial declaration of the Daulah Islamiyah organization that conducted the insurgents in Iraq group is established by az-Zarqawi in 2004 who eventually reveals himself as part of al Qaeda (sahrasad and Chaidar, 2016: 14).

After Az-Zarqawi was killed in battle against the army of the United States in mid-2006, AQI was established by Abu Mus'ab al-Zarqawi from Jordan, who in 2006 was murdered by the United 
States. He was replaced by Abu Ayyoub al-Masri, Egyptian origin, who supports the formation of the Islamic State of Iraq (ISI) or Daulah Islamiyah fil Iraq.

Helm of Daulah Islamiyah fil Iraq switched to Abu Hamza alMohajir until April 19, 2010. He was killed in an attack by American troops. The leadership then falled into the hand of Abu Umar AlBaghdadi for about a year. Then, that helm was transferred to Abu Bakr al-Bagdadi. After standing ISI, Abu-Bakr Al-Baghdadi known as Abu Hamed Dawood Mohammed II or Khalil al-Zawri (Awwad Ibrahim Ali al-Badri al-Samarrai and Abu Bakr al-Husayni al-Qurashi al-Baghdadi) makes Baquba as his headquarters. Al-Baghdadi, the Iraqi people, replaced al-Masri, killed by American troops and Iraqis.

Under the control of Abu Bakr al-Bagdadi, Daulah Islamiyah fil Iraqorganization increasingly expanded its influence until April 9, 2013 when appearing a voice recording associated with the voice of Abu Bakr al-Baghdadi. The tape was stated, Jabhah Nushra (Victory Front) in Syria is a continuation Daulah Islamiyah of Iraqorganization. The tape also described that the name Jabhah Nushrah and Daulah Islamiyah fil Iraq be removed, and later proclaimed Daulah Islamiyah fil Iraq wa ash-Sham, that is written by media as Islamic State in Iraq and Syria (ISIS) or the Islamic State in Iraq and the Levant (ISIL) by Abu Bakr al-Baghdadi as his successor, while Raqqah city located in Syria, which borders with Turkey, as its capital.

In 2012, al-Baghdadi sent his men to form a branch of al Qaeda Syria, named Jabhat al-Nusra. The group aims to get rid of President Bashar al-Assad and establish a Sunni Islamic state led by Abu Muhammad al-Jawlani, a Salafist-oriented leader. According to the Australian National Security, they received funding and support from AQI and ISI. However, they subject to Ayman al-Zawahiri, the leader of $\mathrm{Al}$ Qaeda.

Al-Baghdadi who wants to be a single leader, in 8 April 2003 through a decree stating that AQI and Jabhat al-Nusra turned into ISIS/ISIL. However, Jabhah al-Nusra rejected it. Dispute between the ISIS and Jabhah al-Nusra prolonged and failed to be mediated by Ayman al-Zawahiri that ultimately claimed that Al-Qaeda cut off ties with ISIS because ISIS has its own conception and position; 
not subject to the Al Qaeda and Ayman Center (Clinton, 2014: 6; Kuncahyono, 2014: 8).

According to German radio, Deutsche Welle (DW), ISIS takes money at the Central Bank of Mosul, some 500 billion Iraqi dinars, or about 429 million dollars plus a certain amount of gold. "With that much money, they used to pay 60,000 fighters," said Eliot Higgins, a resident scholar of the UK. Currently, ISIS has estimated about 10,000 armed members from different parts of the world: Europe, Africa, the Middle East, Australia, and Southeast Asia, including Indonesia.

According to the Director of the Center for Research on the Arab World at the University of Mainz, Germany, Gunter Meyer, "The most important financial source of ISIS is the Gulf states and Saudi Arabia, Qatar, Kuwait, and United Arab Emirates," especially from the rich people in the country. The motivation of initial assistance they provide, according to Meyer, is to support the ISIS to face the regime of President Bashar al-Assad in Syria. This support is encouraged "hatred" sectarian: three-quarters of the Syrian population is Sunni Muslim, but most of the ruling elite are the Alawite minority, which is often called the part of the Shia Muslims.

$\mathrm{BBC}$ stated that ISIS received financial support from donors in Syria, Saudi Arabia, Kuwait, and Jordan. It happened when they were still called Al Qaeda in Iraq (AQI). However, after the breakup of AQI with its central leader Ayman al-Zawahiri, and proclaimed ISIS, according to CNN and The New York Times, they rely on the financial resources of criminal acts, such as kidnapping, extortion, and robbery.

Syrian conflict is initially localized, such as demonstrations to topple the regime of Bashar al-Assad, then evolved into an international conflict, involving thousands of combatants from dozens of countries: Saudi Arabia, Iraq, Yemen, Chechnya, Turkey, America, England, France, Germany, Sweden, Japan, Malaysia, and Indonesia.

Santoso, alias Abu Wardah, is an example of a man who was initially radicalized conventionally before the era of radicalization through the internet and social media, which has now become a trend. It was said to be conventional because the radicalization occurred through personal 
approaches and meetings as well as direct physical forging by elements of terror groups, which are neatly structured. The introduction of Santoso to violent networks in the country started many years before the era of the Islamic State (IS) movement. Communal religious conflict in Poso, Central Sulawesi, became the initial channel for Santoso's actualization, which later raised his profile in the circle of violent groups (Sidney Jones: 2011: 20).

The popularity of Santoso seemed to reach its peak in 2014, when he, together with a group he led, the East Indonesia Mujahidin, pledged or declared an oath of loyalty to IS and distributed a voice recording of the oath via YouTube. He also claimed to be an element of IS in Indonesia (Kompas, Juli 20, 2016). Santoso's parents came from Central Java, and migrated to Tambarana, North Poso Pesisir, Central Sulawesi. Around 1999, Santoso learned martial arts from a graduate of Al Mukmin Ngruki Islamic boarding school in Sukoharjo, Central Java. "It is strongly believed that this was when he got an introduction to the [terror] network," said global extremism observer Noor Huda Ismail, who is also a graduate of $\mathrm{Al} \mathrm{Mukmin} \mathrm{Ngruki.}$

In this regard, actors and designers of the Bali bombings, Ali Imron, told the authors that after the murder of Santoso, the future of terrorism could be more desperated and awful, will not easily be killed, let alone embryos of ISIS (Islamic State of Syria and Iraq) in Indonesia has been growing with its global network, where the paradigm of ISIS is that the Muslims who disagree with them as the unbelievers, deserve to be killed, while they are ready to attack the government of a state at any time (Zammit and Iqbal, 2015:3).

There are competing estimates of how many Indonesians are involved with jihadist groups in Syria and Iraq. One of the most widelyused estimates is that up to 500 have joined the conflict, including fighters, but also their wives and families Around 40 have reportedly been killed. Given Indonesia’s Muslim population is an estimated 209 million, 500 people does not represent a dramatically large level of involvement in Syria and Iraq (The Strategist, July 17,2015).

Mujahidin shares the same vision as IS established an Islamic caliphate in 2013 in Iraq then expanded into Syria. However, there was still romanticism among the group's members about establishing their 
own caliphate in Poso as it was the location where they had previously been trained by al-Qaeda and the place where Santoso ran an extremist training camp.

\section{Terrorism in Indonesia: a Tip of an Iceberg?}

In today's era of globalization of terrorism, Santoso Group is just the tip of the iceberg of the real-actual and potential strength of terrorism in Indonesia, that interlaced and connected with global networking, which they have imagined solidarity among globalized Islam radicalists, - to borrow Asef Bayat's perspective, a Middle East expert and Islam Politics from the University of Illinois, Urbana-Champaign, USA. Every terrorist attack anywhere and wherever, in Belgium, France, the US, Turkey, Middle East and so on, tend to trigger resonance, stimulate appetite and motivate terrorist groups in Indonesia to act, in response amid the globalization of terrorism itself.

The spread of the ideology of radical Islamism, according to Oliver Roy-, continued to seep due to injustice, corruption, oppression and socio-economic disparities are increasing sharply tapered. The situation is compounded by, consciously or unconsciously by leaders, elites and the state apparatus, the intrusion of friction or even ideologicalreligious-political conflicts from the level of middle class to the lower class. All too often we see on the television screen how terrorist groups shootout with the police, or the FPI (Front of Islam Defender) and other paramilitary uslims who clashed with officers, and many more such cases.

We have to admit, after the passage of the New Order era, Indonesian reformation era past dozen years, entered a phase of friction and clash of ideology thatis relatively sharp. Religious ideology, often accompanied by violence and other forms of emotional expression, change into an ideology of radical opposition that is strong enough, even with a relatively small number of supporters. In many cases, they are sporadic, brutal and frightening. The ideology of Islam in Indonesia at this period appears in its hardest and roughest form: terrorism.

From the confessions of terrorism suspects of the October 12, 2002 Bali bombings, Imam Samudra, for example, states “... Fighting the US 
and its allies is the command of Allah and His Messenger, either directly or indirectly" and that, clearly an expression of religious emotion. Imam even expressed his attitude to the firm and simple: “... avenge injustice and tyranny of the US and its allies against Muslims with the intention to stop his injustice."

There is a value that works and dictate their minds. Ali Ghufron for example, stated that the bombing was "act of devotion to God." Thus, it is possible Ali Ghufron, Imam Samudra, Amrozi and his group felt a delusion of grandeur, a feeling that they hold or represent or get edicts and become part of the elements of greatness believes himself to carry out a special mission from the God.

The terrorists always felt themselves to be "God's warriors" fighting to Allah (battle for God, to borrow the poetic language of Karen Armstrong) who are called to act in the name of God and religion, to "hand of God" on earth to "realize" wrath in the form of resistance: the bombings and other terrorist acts.

In fact, the Imam Samudera, bombing was carried out the orders of God in the Quran surah An-Nisaa verse 74-76. This is clearly erroneous interpretation, even misguided. As a result of the interpretation and expression of religious emotion that delusive, then tragedy ensued and a large amount of speculation arose in the midst of the public.

\section{Chain of Terrors and the Reign of Speculations}

The attacks of Santoso group and tragedy of terrorist bomb attacks in Bali, Makassar, Jakarta, Ambon, Poso and other places in Indonesia, have led to a series of speculations of the apologists to the a priori. The first speculation is about who the perpetrators of terror attacks were very well planned and carried out by people who have advanced the technical knowledge. The culprit is arbitrarily identified as antiUS / Western, anti-Israel, anti-democratic, anti-capitalist economic strength, and global anti-military.

The second is speculation about the motives of the terrorists in carrying out acts of excessive destruction of places where the strength of the economic, political, and military of the West is located. 
The third speculation is about what the goals that will be aimed towards the US/West and Israel. The culprit is allegedly identified as Islamic fundamentalists who today became the mortal enemy of the United States (US)/West, group of Osama bin Laden who used to hide in Afghanistan.

Osama bin Laden in February 1998 had issued a fatwa against the Jews and the Christians and became a role model for almost all suspected terrorists. In addition to bin Laden, the world community assumes that the culprit is a radical Salafi or the scripturalists and Islamic fundamentalists who have doctrinal relationship with ISIS or $\mathrm{Al}$ Qaeda network or its ramifications and fractions thereof.

Because the United States is present everywhere, anywhere in the world, including in Indonesia, as it is known, the terrorists and the Islam scripturalists/fundamentalist in Indonesia was very characteristic anti-US, anti-Israel, anti-democratic, anti-capitalist, and anti-global military. Their motive, as far as can be analyzed from the character of US foreign policy over the years, is the attitude of hatred toward the US/West-according to them-perception secular, anti-Islamic and too possessive and over-protective of Israel. While speculation about his next target, is the usual response of the loss of a sense of security and fear of the US/Western people requiring an immediate answer to what might happen.

This speculation is reasonable once formed because of this incident was so sudden, massive enough and synchronously with tremendous power destroyed. Speculation is also reasonable because it has caused enormous anger of the people and leaders of the US / West who are comfortable living in modernity, secularism and economic prosperity suddenly have to face an embarrassing nightmare. The US/West People are not the first time the face of the terrorist attacks. For the Islam fundamentalists and radicalist - which lay better known by the term 'the terrorist' - against the US/West is to carrying out personal liability, a global jihad against the Jews and the Christians.

Thus, the US / West also has put Muslim terrorists as enemies since 1979 (which led to the name "Ayatollah Khomeini" as the name for the enemy perceived it) at the time of the Islamic Revolution of Iran and culminated in the events of the gulf crisis of the 1990s (which appears 
the name "Saddam Hussein" as an enemy). With the killing or the arrest of the suspects of terrorism in Indonesia and in some Southeast Asian countries and even in America and Europe, increasingly shows us that the terrorist organization's network is very extensive, aligning globally and mondially (Mydans, 2001).

Although morally and international diplomacy terrorists attacked the "war discourse" are pushing them as "the coward", "extremists, the savages", "the inhuman", "people are happy at the expense of others", and "the mental illness", but the terrorists are constantly emerging in the political map of Indonesia and the world until now to deliver messages that are very difficult to interpret (The Economist, February 15, 1992:45-46).

Because the so hidden enemy of this one, it has given to the rising impression of mystery and the psychological fear itself. For the people of the US / West, terrorism is a ghost (Specter) others who have faced the US / West after phantom of communism gone, a form of ideological enemy, as well as the new spiritual enemy ever remind magnified by Samuel Huntington (1996: 67) in the Clash of Civilization. Douglas E. Streusand (1992: 121) even dared to mention "that Specter is Islam", which was later identified by the public in layman AS / West as "green peril”, the dangerous Green (Hadar, 1992: 77).

And, with the events of the attack on the WTC and Pentagon 11.09.2001, the name of Osama bin Laden emerged as an "enemy" to restore the trust of the public AS / West against his government in dealing with terrorism from Muslims. For us, in the context of Indonesia as the largest Muslim country in the world, the problem of terrorism raises many dilemmas: between keeping the feelings of Muslims and law enforcement, the rule of law, which must be enforced.

Moreover, there is a fact that the attack of Santoso group and other brutal terrorist attacks has taken place, so the state enemy must be defined to then take the next steps before executing the terrorists as "criminals", although they continue to hide behind the religious symbols and reasons. Terrorism is a crime against humanity, that is an extraordinary crime that must be solved by Indonesian state and society.[] 


\section{References}

Abdurrahman Wahid, Ilusi Negara Islam (Jakarta: Maarif and Wahid Institute, 2011.

Andrew Zammit, Muhammad Iqbal, Indonesia's New Counter-Terrorism Challenges, Publication: Terrorism Monitor Volume: 13 Issue: 18, September 3, 2015.

Bruce Vaughn, ( et al.), Terrorism in South East Asia, CRS Report for Congress, February 7, 2005.

Jamhari and Jajang Jahroni (eds.), Gerakan Salafi Radikal di Indonesia, Rajawali Press, Jakarta, 2004.

Khamami Zada, Islam Radikal: Pergulatan Ormas-Ormas Islam Garis Keras di Indonesia, Teraju, Jakarta, 2002.

Madar Hilmy, Ending the Reproduction of Terrorism, Kompas, July 26, 2016.

Noorhaidi Hasan, "Faith and Politics: The Rise of Laskar Jihad in the Era of Transition in Indonesia", jurnal Indonesia 73, (April 2002).

International Crisis Group Report, Jemaah Islamiyah in South East Asia: Damaged but Still Dangerous, 26 August 2003.

Rohan Gunaratna, Inside Al Qaeda: Global Network of Terror (New York: Columbia University Press, 2002).

Saiful Mujani, Muslim Demokrat, Islam, Budaya Demokrasi, dan Partisipasi Politik diIndonesia Pasca-orde Baru (Jakarta: Gramedia, 2007).

Sukawarsani Djelantik, "Terrorism in Indonesia: The Emergence of West Javanese Terrorist." International Graduate Student Conference Series, No. 22, (EastWest Center, 2006).

Herdi Sahrasad and Al Chaidar, ISIS, Indonesian Muslims and the Global Ultra Revivalists for Global Terrorism: A Perspective, working paper, Freedom Foundation and PSIK, Paramadina University, Jakarta, July 2016.

Hillary Rodham Clinton, Hard Choices, New York: Simon \& Schuster, 2014, p. 6. Elmihwar, newspaper, Egypt (6/8/2014).

Trias Kuncahyono, "Radikalisme: Genesis ISIS", Kompas, August 2, 2014.

Seth Mydans, 'Militant Islam Unsettles Indonesia And Its Region', New York Times, 21 September 2001.

Samuel Huntington, The Clash of Civilizationand the Remaking of World Order, Simon and Schuster, 1996.

Leon T. Hadar, "The Green Peril: Creating the Islamic Fundamentalist Threat", Policy Analysis No. 77 August 27, 1992.

\section{Newspapers and online media:}

Antara, 21 Juli 2009.

Metrotvnews. 17 Januari 2016. Diakses tanggal January 17, 2016. 
22 - Herdi Sahrasad \& Al Chaidar

Kompas, August 9, 2003.

Jakarta Post, April 26, 2013.

The Jakarta Post, August 8, 2009.

Kompas, 20 Juli 2016.

The Strategist, July 17, 2015.

The Economist, February 15, 1992.

Interview with Ali Imron in Jakarta, 30 Juli 2016. 


\section{Mhliam}

AHKAM Jurnal Ilmu Syariah (ISSN: 1412-4734/E-ISSN: 2407-8646) is a periodical scientific journal published by Faculty of Sharia and Law of Syarif Hidayatullah State Islamic University Jakarta in collaboration with Indonesian Scientist and Sharia Scholar Association (HISSI). This journal specifically examines the science of sharia and obtains to present various results of current and eminence scientific research. The administrators receive articles as contributions Sharia and Islamic law disciplines from scientists, scholars, professionals, and researchers to be published and disseminated. The article will be situated in a selection mechanism, a review of proved reders, and a strict editing process. All articles published in this Journal are based on the views of the authors, but they do not represent the authors' journals or affiliated institutions.

AHKAM has been accredited based on the determination of Director General of Research Reinforcement and Development, Research, and Technology Ministry of Higher Education of Republic of Indonesia, No. 36/a/E/KPT/2016 (valid until 2021). 